\title{
Pyruvate Protects Neurons against Hydrogen Peroxide-Induced Toxicity
}

\author{
Solange Desagher, Jacques Glowinski, and Joël Prémont \\ Chaire de Neuropharmacologie, Institut National de la Santé et de la Recherche Médicale U114, Collège de France, \\ 75231 Paris Cedex 05, France
}

Hydrogen peroxide $\left(\mathrm{H}_{2} \mathrm{O}_{2}\right)$ is suspected to be involved in numerous brain pathologies such as neurodegenerative diseases or in acute injury such as ischemia or trauma. In this study, we examined the ability of pyruvate to improve the survival of cultured striatal neurons exposed for 30 min to $\mathrm{H}_{2} \mathrm{O}_{2}$, as estimated $24 \mathrm{hr}$ later by the 3-[4,5-dimethylthiazol-2-yl]-2,5diphenyltetrazoliumbromide assay. Pyruvate strongly protected neurons against both $\mathrm{H}_{2} \mathrm{O}_{2}$ added to the external medium and $\mathrm{H}_{2} \mathrm{O}_{2}$ endogenously produced through the redox cycling of the experimental quinone menadione. The neuroprotective effect of pyruvate appeared to result rather from the ability of $\alpha$ ketoacids to undergo nonenzymatic decarboxylation in the presence of $\mathrm{H}_{2} \mathrm{O}_{2}$ than from an improvement of energy metabolism. Indeed, several other $\alpha$-ketoacids, including $\alpha$ ketobutyrate, which is not an energy substrate, reproduced the neuroprotective effect of pyruvate. In contrast, lactate, a neu- ronal energy substrate, did not protect neurons from $\mathrm{H}_{2} \mathrm{O}_{2}$. Optimal neuroprotection was achieved with relatively low concentrations of pyruvate $(\leq 1 \mathrm{~mm})$, whereas at high concentration (10 $\mathrm{mm}$ ) pyruvate was ineffective. This paradox could result from the cytosolic acidification induced by the cotransport of pyruvate and protons into neurons. Indeed, cytosolic acidification both enhanced the $\mathrm{H}_{2} \mathrm{O}_{2}$-induced neurotoxicity and decreased the rate of pyruvate decarboxylation by $\mathrm{H}_{2} \mathrm{O}_{2}$. Together, these results indicate that pyruvate efficiently protects neurons against both exogenous and endogenous $\mathrm{H}_{2} \mathrm{O}_{2}$. Its low toxicity and its capacity to cross the blood-brain barrier open a new therapeutic perspective in brain pathologies in which $\mathrm{H}_{2} \mathrm{O}_{2}$ is involved.

Key words: pyruvate; $\alpha$-ketoacids; antioxidants; hydrogen peroxide; menadione; oxidative stress; neuroprotection; neurotoxicity
Oxygen-derived free radical generation has been implicated in the etiology of some neurodegenerative diseases (Olanow, 1993; Simonian and Coyle, 1996) and in neuronal death after acute injury such as ischemia-reperfusion or trauma (Siesjö et al., 1989; Traystman et al., 1991). In particular, superoxide anion $\left(\mathrm{O}_{2}{ }^{-}\right)$, which has limited toxic effects in itself, can either react with nitric oxide to form peroxinitrite anions, which are highly cytotoxic, or dismutate into hydrogen peroxide $\left(\mathrm{H}_{2} \mathrm{O}_{2}\right)$, a reaction that is accelerated by superoxide dismutase. In turn, $\mathrm{H}_{2} \mathrm{O}_{2}$ can exert its toxic effects mainly through the ferrous iron-dependent formation of the highly reactive hydroxyl radical $\left(\mathrm{OH}^{\circ}\right)$ (Fenton, 1894), which leads to alterations of lipids, proteins, and DNA (Halliwell, 1992). Probably of less importance, the modification of the redox thiol status of the cytosol could also contribute to $\mathrm{H}_{2} \mathrm{O}_{2}$ toxicity.

Under pathological situations such as ischemia-reperfusion, various cell types including neurons produce large amounts of $\mathrm{H}_{2} \mathrm{O}_{2}$. Because of its high membrane permeability (Halliwell, 1992), $\mathrm{H}_{2} \mathrm{O}_{2}$ can be cytotoxic not only for the producing cell but also for neighboring cells. As generally accepted, the enzymatic cellular defense against $\mathrm{H}_{2} \mathrm{O}_{2}$ includes catalase and glutathione peroxidase (Simonian and Coyle, 1996). We have recently reported that catalase plays a predominant protecting role against

Received June 6, 1997; revised Sept. 17, 1997; accepted Sept. 23, 1997.

This study was supported by Institut National de la Santé et de la Recherche Médicale, Direction des Recherches Etudes et Techniques Grant 94158, and Rhône-Poulenc-Rorer.

Correspondence should be addressed to Solange Desagher, Chaire de Neuropharmacologie, Institut National de la Santé et de la Recherche Médicale U114, Collège de France, 11 place Marcelin Berthelot, 75231 Paris Cedex 05, France.

Copyright (C) 1997 Society for Neuroscience $0270-6474 / 97 / 179060-08 \$ 05.00 / 0$
$\mathrm{H}_{2} \mathrm{O}_{2}$ within astrocytes, whereas glutathione peroxidase is the main protective enzyme in neurons (Desagher et al., 1996).

However, nonenzymatic mechanisms can also contribute to the cellular defense against $\mathrm{H}_{2} \mathrm{O}_{2}$-induced cytotoxicity. Indeed, pyruvate and other $\alpha$-ketoacids, abundantly present in mammalian cells, can react nonenzymatically with $\mathrm{H}_{2} \mathrm{O}_{2}$. Through this reaction first described by Holleman (1904), carbon dioxide is liberated, and the $\alpha$-ketoacid is converted into the corresponding carboxylic acid: $\mathrm{R}-\mathrm{CO} \mathrm{COOH}+\mathrm{H}_{2} \mathrm{O}_{2} \rightarrow \mathrm{R}-\mathrm{COOH}+\mathrm{CO}_{2}$ $+\mathrm{H}_{2} \mathrm{O}$.

Pyruvate can be transported into or secreted from the cells by the specific $\mathrm{H}^{+}$-monocarboxylate cotransporter (Poole and Halestrap, 1993; Garcia et al., 1994). It could thus act as both intracellular and extracellular $\mathrm{H}_{2} \mathrm{O}_{2}$ scavengers. The present study was undertaken to determine whether pyruvate and other $\alpha$-ketoacids can indeed protect neurons against $\mathrm{H}_{2} \mathrm{O}_{2}$. Cultured striatal neurons from mouse embryos were exposed to either exogenous $\mathrm{H}_{2} \mathrm{O}_{2}$ or to $\mathrm{H}_{2} \mathrm{O}_{2}$ intracellularly formed as a result of the use of menadione (2-methyl-1,4-naphthoquinone), a quinone that generates intracellular $\mathrm{O}_{2}{ }^{--}$and $\mathrm{H}_{2} \mathrm{O}_{2}$, through a redox cycling process (Thor et al., 1982; Doroshow, 1986). We demonstrate that pyruvate protects neurons against both exogenous and endogenously produced $\mathrm{H}_{2} \mathrm{O}_{2}$.

\section{MATERIALS AND METHODS}

Materials. Swiss mice were obtained from Iffa Credo (Lyon, France); PBS without calcium and magnesium and culture media were from Life Technologies (Gaithersburg, MD); fetal calf serum was from Dutcher (Brumath, France); 5- and 6-carboxy-SNARF-1 AM acetate (lot 2651-4) was from Molecular Probes Europe BV (Leiden, The Netherlands); water, $\left[{ }^{3} \mathrm{H}\right]$ carboxyl $(1.0 \mathrm{mCi} / \mathrm{g})$, and inulin-carboxyl [carboxyl- $\left.{ }^{14} \mathrm{C}\right](2.2$ 
$\mathrm{mCi} / \mathrm{g}$ ) were from DuPont NEN; horseradish peroxidase, catalase (bovine liver), L-lactic acid dehydrogenase (LDH, type XI from rabbit muscle), $o$-dianisidine $\left(3,3^{\prime}\right.$-dimethoxybenzidine $), \beta$-nicotinamide adenine dinucleotide reduced form ( $\beta$-NADH) disodium salt, $\mathrm{H}_{2} \mathrm{O}_{2}$, pyruvic acid sodium salt, L-(+)-lactic acid sodium salt, $\alpha$-ketoglutaric acid monosodium salt, $\beta$-ketoglutaric acid, oxaloacetic acid, $\alpha$-ketobutyric acid sodium salt, menadione (2-methyl-1,4-naphthoquinone) sodium bisulfite, $N$-morpholinopropanesulfonic acid, 2-deoxy-D-glucose, 3-[4,5dimethylthiazol-2-yl]-2,5-diphenyltetrazoliumbromide (MTT), phloretin, and all other chemicals or reagents used in the present study were purchased from Sigma (Saint Quentin Fallavier, France).

Primary culture of striatal neurons. Primary neuronal cultures were prepared using the method of El Etr et al. (1989) with slight modifications. Briefly, striata were removed from 14- to 15-d-old Swiss mouse embryos and mechanically dissociated with a flame-narrowed Pasteur pipette in PBS supplemented with glucose $(33 \mathrm{~mm})$. Cells were plated on 24-well Nunc (Roskilde, Denmark) culture dishes $\left(5 \times 10^{5}\right.$ cells per well containing $0.5 \mathrm{ml}$ of medium) or $50 \mathrm{~mm}$ Nunc petri dishes $\left(5 \times 10^{6}\right.$ cells per dish in $5 \mathrm{ml}$ ), previously and successively coated with poly-Lornithine $\left(15 \mu \mathrm{g} / \mathrm{ml} ; M_{\mathrm{r}} 40 \mathrm{kDa}\right)$, and the culture medium containing $10 \%$ fetal calf serum. After the removal of the last coating solution, cells were seeded in a serum-free medium consisting of a 1:1 mixture of DMEM and Ham's F12 nutrient, supplemented with glucose (33 mM), glutamine (2 mM), $\mathrm{NaHCO}_{3}(13 \mathrm{~mm})$, HEPES buffer (5 mM, pH 7.4), penicillin-streptomycin ( $5 \mathrm{IU} / \mathrm{ml}$ and $5 \mu \mathrm{g} / \mathrm{ml}$, respectively), and a mixture of salt and hormones containing insulin $(25 \mu \mathrm{g} / \mathrm{ml})$, transferrin $(100 \mu \mathrm{g} / \mathrm{ml})$, progesterone $(20 \mathrm{nM})$, putrescine $(60 \mu \mathrm{M})$, and sodium selenite $(30 \mathrm{nM})$. Cells were cultured at $37^{\circ} \mathrm{C}$ in a humidified atmosphere of $92 \%$ air and $8 \% \mathrm{CO}_{2}$. After 1 week in culture, cells were immunocytochemically defined according to the method of El Etr et al. (1989) as purified neurons devoid of detectable glial elements. Neurons were used at 6-7 d in vitro.

Neurotoxicity experiments. Neurons were first washed with Krebs' bicarbonate buffer (in mM: $124 \mathrm{NaCl}, 3.5 \mathrm{KCl}, 1.25 \mathrm{~K}_{2} \mathrm{HPO}_{4}, 26.3$ $\mathrm{NaHCO}_{3}, 1.2 \mathrm{CaCl}_{2}, 1.2 \mathrm{MgSO}_{4}$, and 11 glucose, equilibrated with $92 \%$ air and $8 \% \mathrm{CO}_{2}$ at $37^{\circ} \mathrm{C}$, $\mathrm{pH}$ 7.4) or preincubated for indicated times in the presence of different agents. Cells were then incubated in the same buffer at $37^{\circ} \mathrm{C}$ in a humidified atmosphere $\left(92 \%\right.$ air and $\left.8 \% \mathrm{CO}_{2}\right)$ with $\mathrm{H}_{2} \mathrm{O}_{2}$ or menadione for the indicated time. After the incubation period, cells were washed with Krebs' bicarbonate buffer and cultured for another period of $24 \mathrm{hr}$ in the initial culture medium previously stored.

To investigate the influence of intracellular acidification on the neurotoxic effect of $\mathrm{H}_{2} \mathrm{O}_{2}$, neurons were successively preincubated and incubated with $\mathrm{H}_{2} \mathrm{O}_{2}$ in a buffer containing (in $\mathrm{mM}$ ): $130 \mathrm{NaCl}, 5 \mathrm{KCl}, 1$ $\mathrm{CaCl}_{2}, 1.2 \mathrm{MgCl}_{2}, 20 \mathrm{HEPES}$, and 11 glucose, adjusted to the indicated $\mathrm{pH}$ with $\mathrm{NaOH}$.

MTT colorimetric assay. Previously, we estimated the survival of striatal neurons $24 \mathrm{hr}$ after the exposure to $\mathrm{H}_{2} \mathrm{O}_{2}$ by two different methods: the MTT assay and an ELISA with antibodies directed against an antigen specifically located in neurons (microtubule-associated protein-2) (Desagher et al., 1996). The two methods gave exactly the same results. Therefore, the more convenient and rapid method, i.e., the MTT colorimetric assay, was used in the present study.

This method is based on reduction of the tetrazolium salt MTT into a crystalline blue formazan product by the cellular oxidoreductases (Slater et al., 1963; Berridge and Tan, 1993). Therefore, the amount of formazan produced is proportional to the number of viable cells. Briefly, the culture medium was replaced by a solution of MTT $(0.5 \mathrm{mg} / \mathrm{ml})$ in PBS supplemented with glucose $(33 \mathrm{~mm})$. After a $3 \mathrm{hr}$ incubation at $37^{\circ} \mathrm{C}$, this solution was removed, and the produced blue formazan was solubilized in $1 \mathrm{ml}$ of pure dimethyl sulfoxide. The optical density of the formed blue formazan was measured at $560 \mathrm{~nm}$.

Determination of $\mathrm{H}_{2} \mathrm{O}_{2}$ concentration. The concentrations of $\mathrm{H}_{2} \mathrm{O}_{2}$ were estimated with a colorimetric assay using $o$-dianisidine $\left(3,3^{\prime}\right.$ dimethoxybenzidine). This compound, which is colorless in its reduced form, is oxidized in the presence of $\mathrm{H}_{2} \mathrm{O}_{2}$ and peroxidase into a red product. The sample was added to $0.5 \mathrm{~mm} o$-dianisidine and $60 \mathrm{IU} / \mathrm{ml}$ horseradish peroxidase. $\mathrm{H}_{2} \mathrm{O}_{2}$ reacted instantaneously and totally with $o$-dianisidine. Optical density was estimated at $500 \mathrm{~nm}$. The concentrations of $\mathrm{H}_{2} \mathrm{O}_{2}$ were determined using standard solutions.

Fluorimetric determination of intracellular pyruvate content. After different treatments, neurons, cultured in $50 \mathrm{~mm}$ dishes, were rapidly washed twice with ice-cold PBS containing $100 \mu \mathrm{M}$ phloretin, an inhibitor of the monocarboxylate transporter (Poole and Halestrap, 1993), and all the buffer was carefully aspirated. Cells were incubated in $500 \mu \mathrm{l}$ of 0.25
M ice-cold perchloric acid for 5 min, scraped with a rubber policeman, and centrifuged at $12,000 \times g$ for $5 \mathrm{~min}$ to remove proteins. The supernatant was neutralized with a solution containing $2 \mathrm{M} \mathrm{KOH}$ and 0.3 M $N$-morpholinopropanesulfonic acid. Catalase $(500 \mathrm{IU} / \mathrm{ml})$ was then added to ensure the stability of pyruvate. After centrifugation and elimination of the potassium perchlorate formed, the samples were stored at $-20^{\circ} \mathrm{C}$ before use.

The fluorimetric assay was a modification of the method of Lowry and Passonneau (1972). Pyruvate and NADH were respectively converted into lactate and NAD by LDH. The decrease of NADH fluorescence (excitation, $340 \mathrm{~nm}$; emission, $460 \mathrm{~nm}$ ) was followed by a Hitachi F-2000 fluorescence spectrophotometer. Each sample was mixed with Tris- $\mathrm{HCl}$ buffer (100 mM, pH 7.4) containing an NADH concentration that exceeded the expected pyruvate concentration at least fivefold. The reaction was started by adding $\mathrm{LDH}(4.6 \mathrm{IU} / \mathrm{ml})$, and the fluorescence was followed until no further change was observed. The concentrations of pyruvate were determined using standard solutions.

In each assay, the protein content was determined in $50 \mathrm{~mm}$ dishes of sister cultures by the method of Bradford (1976) with bovine serum albumin as the standard. The intracellular water volume of cultured neurons was estimated according to the method of Rottenberg (1979) by the use of tritiated water and $\left[{ }^{14} \mathrm{C}\right]$ inulin.

Cytosolic $\mathrm{pH}$ measurements. For measurements of intracellular $\mathrm{pH}$ ( $\mathrm{pHi})$, cells were cultured on glass slides $\left(6 \times 10^{6}\right.$ cells per slide $)$, coated successively with poly-L-ornithine $(15 \mu \mathrm{g} / \mathrm{ml})$ and culture medium supplemented with $10 \%$ fetal calf serum and $1 \mu \mathrm{g} / \mathrm{ml}$ laminin, and placed into $100 \mathrm{~mm}$ culture dishes. Intracellular $\mathrm{pH}$ was monitored by quantitative ratio imaging of the fluorescent dye 5- and 6-carboxy SNARF-1 AM acetate (Whitaker et al., 1991). Cells were loaded for 45 min with 17 $\mu \mathrm{M}$ SNARF-1 AM in perfusion buffer (in mM: 20 HEPES, 5.5 glucose, $120 \mathrm{NaCl}, 5 \mathrm{KCl}, 1 \mathrm{MgCl}_{2}$, and $1.2 \mathrm{CaCl}_{2}, \mathrm{pH}$ 7.4). After loading, the glass slide was placed in a perfusion chamber where cells were exposed to tested substances using a multichannel superfusion device. Cells were excited with a $75 \mathrm{~W}$ Xenon light, filtered at $535 \mathrm{~nm}$ with a 10 -nm-wide interferential filter. Excitation and emission spectra were separated by a $560 \mathrm{~nm}$ dichroic long-pass filter, and the emission spectra were divided in two halves (opticals were obtained from Nikon and Hamamatsu). Two discriminant bands were selected from the two halves at 580 and $640 \mathrm{~nm}$, and both fluorescent images were digitized (eight video frames per digitized image, permitting the recording of one image per second). The camera dark noise was substracted from the recorded crude image (camera and digitizing system were from Hamamatsu). Fields for imaging were selected under bright-field illumination before any fluorescence measurement and contained 7-21 healthy, intact neurons. In situ calibration of $\mathrm{pHi}$, measured with SNARF-1, was performed by exposing cells to nigericin $(10 \mu \mathrm{M})$, along with high $\mathrm{K}^{+}(100 \mathrm{mM})$ buffers (Thomas et al., 1979) ranging from $\mathrm{pH} 6.5$ to 7.5 .

\section{RESULTS}

\section{Pyruvate protects neurons from the toxicity induced by exogenous $\mathrm{H}_{2} \mathrm{O}_{2}$}

Cultured striatal neurons were incubated for $30 \mathrm{~min}$ with increasing concentrations of $\mathrm{H}_{2} \mathrm{O}_{2}$ in the absence or presence of $2 \mathrm{~mm}$ sodium pyruvate. Pyruvate $(2 \mathrm{~mm})$ completely protected neurons from the $\mathrm{H}_{2} \mathrm{O}_{2}$-induced toxicity up to $300 \mu \mathrm{M}$ (Fig. 1), an $\mathrm{H}_{2} \mathrm{O}_{2}$ concentration higher than that measured during the ischemiareperfusion period (Hyslop et al., 1995). The neuroprotective effect of pyruvate was only partial when $\mathrm{H}_{2} \mathrm{O}_{2}$ was added at $1 \mathrm{~mm}$ (Fig. 1). When exposed to $200 \mu \mathrm{M} \mathrm{H}_{2} \mathrm{O}_{2}$, striatal neurons were progressively protected by increasing concentrations of pyruvate. This neuroprotection was already significant for a pyruvate concentration of $0.4 \mathrm{~mm}$ and almost complete at $2 \mathrm{~mm}$ (Fig. 1). The same neuroprotective effects of pyruvate were observed if neuronal survival was measured using ELISA with antibodies directed against microtubule-associated protein-2 (not shown).

\section{Pyruvate protects neurons from the toxicity induced by menadione}

The capacity of pyruvate to protect neurons against endogenously produced $\mathrm{H}_{2} \mathrm{O}_{2}$ was investigated with the use of menadione. Like other quinones, menadione can enter flavoprotein-catalyzed re- 


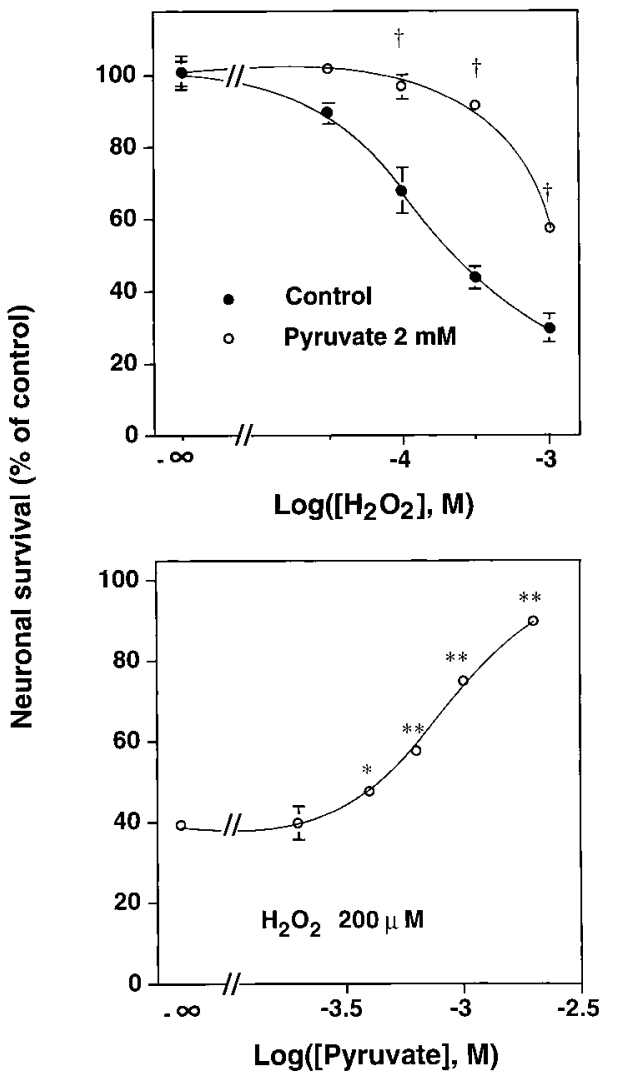

Figure 1. Pyruvate protects neurons from exogenous $\mathrm{H}_{2} \mathrm{O}_{2}$-induced toxicity. Primary cultures of striatal neurons were preincubated in Krebs' bicarbonate buffer at $37^{\circ} \mathrm{C}$ for $30 \mathrm{~min}$ with $2 \mathrm{~mm}$ (top) or increasing concentrations (bottom) of sodium pyruvate and then further incubated for $30 \mathrm{~min}$ with increasing concentrations of $\mathrm{H}_{2} \mathrm{O}_{2}$ (top) or with $200 \mu \mathrm{M}$ $\mathrm{H}_{2} \mathrm{O}_{2}$ (bottom) in the presence or absence of the indicated concentration of pyruvate. Pyruvate and $\mathrm{H}_{2} \mathrm{O}_{2}$ were simultaneously applied to the cells Neuronal survival was estimated $24 \mathrm{hr}$ later by the MTT colorimetric assay. Results are expressed as the percentage of surviving neurons compared with control cultures. Data are the mean \pm SEM of three independent experiments, each performed on triplicate wells. When not visible, the sizes of the error bars are less than those of the symbols. ${ }^{\dagger} p<$ 0.001 ; significantly different from the corresponding values determined in the absence of pyruvate (ANOVA followed by Bonferroni's test). ${ }^{*} p<$ $0.05 ;{ }^{* *} p<0.01$; significantly different from the value obtained in the absence of pyruvate (ANOVA followed by Dunnett's test).

dox cycles with molecular oxygen, and this results in the formation of large amounts of $\mathrm{O}_{2}{ }^{\cdot-}$ (Thor et al., 1982). Because of the subsequent dismutation of $\mathrm{O}_{2}{ }^{\cdot-}$, toxic concentrations of $\mathrm{H}_{2} \mathrm{O}_{2}$ are then intracellularly formed, as demonstrated by the direct estimation of $\mathrm{H}_{2} \mathrm{O}_{2}$ released from neurons (Nath et al., 1995; Desagher et al., 1996).

Exposure of striatal neurons to increasing concentrations of menadione $(5-15 \mu \mathrm{M})$ for $1 \mathrm{hr}$ induced a progressive cell death that was significantly reduced by $1 \mathrm{~mm}$ sodium pyruvate (Fig. 2 ). This protective effect of pyruvate was observed if the $\alpha$-ketoacid was added in the incubation medium and in the culture medium for $24 \mathrm{hr}$ after menadione exposure. Indeed, the quinone produced $\mathrm{H}_{2} \mathrm{O}_{2}$ in the cells even after this compound was removed from the incubation medium. The pyruvate protection was significant for all neurotoxic concentrations of menadione (Fig. 2). Conversely, in the presence of 10 $\mu \mathrm{M}$ menadione, increasing concentrations of pyruvate (up to 1

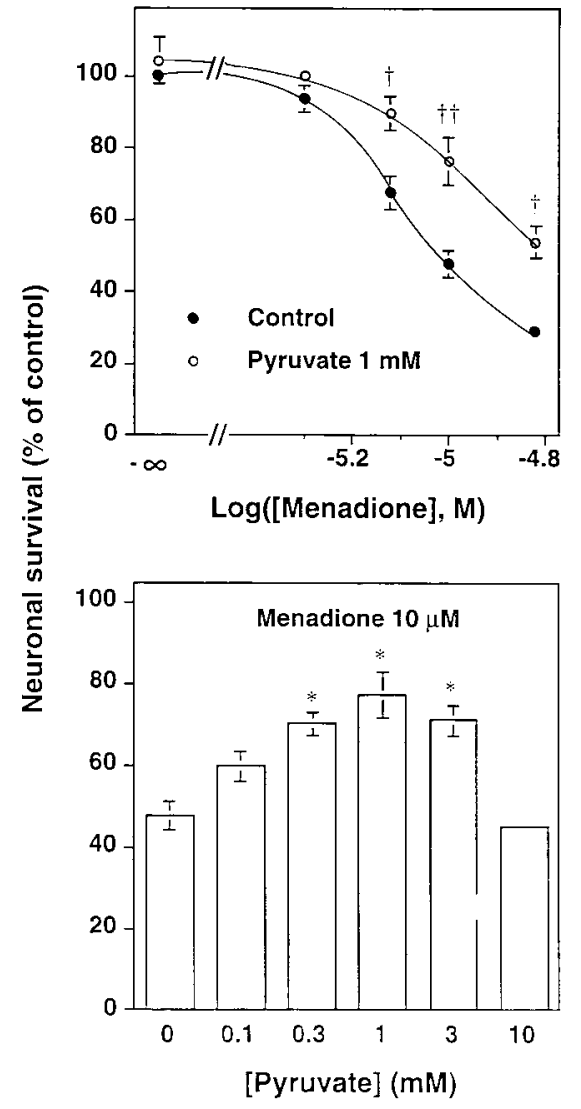

Figure 2. Pyruvate partly protects neurons from menadione-induced toxicity. Primary cultures of neurons were incubated in Krebs' bicarbonate buffer at $37^{\circ} \mathrm{C}$ for $1 \mathrm{hr}$ with increasing concentrations of menadione in the absence or the presence of $1 \mathrm{~mm}$ sodium pyruvate (top) or with $10 \mu \mathrm{M}$ menadione in the presence of increasing concentrations of pyruvate (bottom). Cells were then washed and further incubated for $30 \mathrm{~min}$ with or without pyruvate and replaced into the initial culture medium supplemented with the corresponding concentrations of pyruvate. Neuronal survival was estimated $24 \mathrm{hr}$ later. Results are expressed as the percentage of surviving neurons compared with control cultures not treated with menadione. Data are the mean \pm SEM of three independent experiments, each performed on triplicate wells. ${ }^{\dagger} p<0.01 ;{ }^{\dagger \dagger} p<0.001$; significantly different from the corresponding values determined in the absence of pyruvate (ANOVA followed by Bonferroni's test). ${ }^{*} p<0.01$; significantly different from the value obtained in the absence of pyruvate (ANOVA followed by Dunnett's test).

$\mathrm{mm}$ ) produced a progressive enhancement of the neuronal survival observed $24 \mathrm{hr}$ later (Fig. 2). The lack of protection observed with the highest concentration of pyruvate tested (10 $\mathrm{mm}$ ) might be attributable to the intracellular acidification that counteracts the beneficial effect of pyruvate (see below). The addition of $10 \mathrm{~mm}$ sodium pyruvate alone did not significantly change the cell viability (not shown).

Catalase reduced the neurotoxicity of menadione. This result suggests that $\mathrm{H}_{2} \mathrm{O}_{2}$ released in the extracellular medium contributes to the toxic effect of the quinone through a paracrine mechanism $(33 \pm 2$ and $61 \pm 2 \%$ of neuronal survival estimated $24 \mathrm{hr}$ after exposure to $10 \mu \mathrm{M}$ menadione for $1 \mathrm{hr}$ in the absence or the presence of $500 \mathrm{IU} / \mathrm{ml}$ catalase, respectively, mean $\pm \mathrm{SEM}$, from three independent experiments performed in triplicates). However, at optimal concentration (1 $\mathrm{mm})$, pyruvate was found to be more efficient than catalase to protect neurons (Fig. 2). 


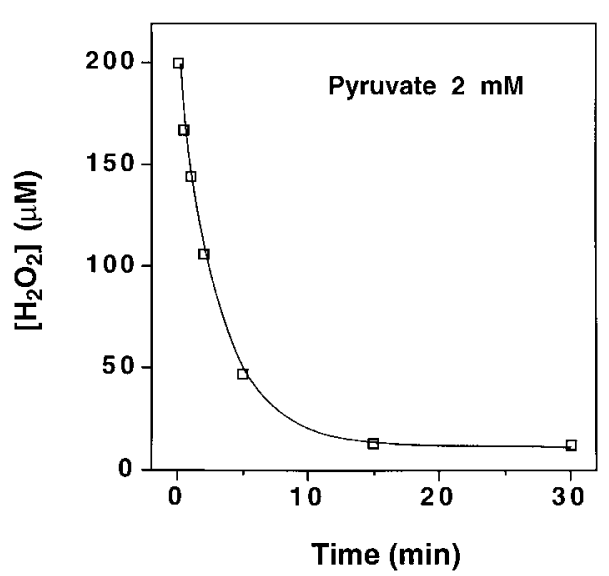

Figure 3. Kinetics of the reaction of $\mathrm{H}_{2} \mathrm{O}_{2}$ and pyruvate in the absence of cells. Pyruvate $(2 \mathrm{mM})$ and $\mathrm{H}_{2} \mathrm{O}_{2}(200 \mu \mathrm{M})$ were mixed in Krebs' bicarbonate buffer at $37^{\circ} \mathrm{C}$ in the absence of cells. The residual concentrations of $\mathrm{H}_{2} \mathrm{O}_{2}$ were determined at indicated times as described in Materials and Methods. Data are the mean \pm SEM of three independent experiments each performed in triplicate. The error bars are not visible, because they are smaller than the symbols.

\section{Mechanisms involved in the neuroprotective effects of pyruvate and other $\alpha$-ketoacids against $\mathrm{H}_{2} \mathrm{O}_{2}$ neurotoxicity}

As already indicated (see the introductory remarks), the neuroprotective effect of pyruvate against $\mathrm{H}_{2} \mathrm{O}_{2}$ toxicity may be attributable to its ability to degrade $\mathrm{H}_{2} \mathrm{O}_{2}$ through a nonenzymatic oxidative decarboxylation, leading to the formation of carbon dioxide, water, and acetate (Holleman, 1904; Bunton, 1949). This reaction may occur both in the extracellular and intracellular medium, leading to the degradation of equal amounts of $\mathrm{H}_{2} \mathrm{O}_{2}$ and pyruvate. However, to be neuroprotective, pyruvate must react with $\mathrm{H}_{2} \mathrm{O}_{2}$ before the formation of $\mathrm{OH}^{\circ}$ and the subsequent appearance of irreversible damage.

Therefore, to determine whether the degradation rate of $\mathrm{H}_{2} \mathrm{O}_{2}$ by pyruvate is compatible with its neuroprotective effect, the rate of the reaction was estimated using respective concentrations of pyruvate and $\mathrm{H}_{2} \mathrm{O}_{2}$, leading to an almost complete neuronal protection (Fig. 3). Pyruvate $(2 \mathrm{mM})$ and $\mathrm{H}_{2} \mathrm{O}_{2}(200 \mu \mathrm{M})$ were mixed in Krebs' bicarbonate buffer at $37^{\circ} \mathrm{C}$, and $\mathrm{H}_{2} \mathrm{O}_{2}$ levels were estimated at various times after the onset of the reaction. In this condition, half of the $\mathrm{H}_{2} \mathrm{O}_{2}$ initially present remained in the medium after $2 \mathrm{~min}$, and $\mathrm{H}_{2} \mathrm{O}_{2}$ levels became negligible after 15 min (Fig. 3). Therefore, cultured neurons were exposed to high levels of $\mathrm{H}_{2} \mathrm{O}_{2}$ only during the first $5 \mathrm{~min}$, and as demonstrated previously, this is insufficient to induce significant cell death (Desagher et al., 1996). Pyruvate may thus protect neurons against $\mathrm{H}_{2} \mathrm{O}_{2}$-induced toxicity by reacting with the oxidant. The rate of the reaction might account also for the reduced protective effect of pyruvate when the $\left[\mathrm{H}_{2} \mathrm{O}_{2}\right] /$ [pyruvate] ratio was increased (Fig. 1). Sodium acetate $(200 \mu \mathrm{M})$, the decarboxylation product of sodium pyruvate, did not significantly modify neuronal viability either in control conditions or in the presence of $200 \mu \mathrm{M} \mathrm{H} \mathrm{H}_{2} \mathrm{O}_{2}$ (Table 1).

Complementary experiments were performed to determine whether pyruvate could also protect neurons against $\mathrm{H}_{2} \mathrm{O}_{2}$ toxicity by improving energy metabolism. For this purpose, striatal neurons were exposed for $30 \mathrm{~min}$ to $\mathrm{H}_{2} \mathrm{O}_{2}(200 \mu \mathrm{M})$ in the presence of $\alpha$-ketoglutarate and oxaloacetate, which are known to act both as $\mathrm{H}_{2} \mathrm{O}_{2}$ scavengers and energy substrate metabolites,
Table 1. Effect of sodium acetate on neuronal survival

\begin{tabular}{lc} 
Treatment & $\begin{array}{l}\text { Neuronal survival } \\
\text { (\% of control) }\end{array}$ \\
\hline Control & $100 \pm 2.4$ \\
Acetate $(200 \mu \mathrm{M})$ & $105.9 \pm 0.5 \mathrm{NS}$ \\
$\mathrm{H}_{2} \mathrm{O}_{2} 200(\mu \mathrm{M})$ & $46.9 \pm 2.8$ \\
$\mathrm{H}_{2} \mathrm{O}_{2}(200 \mu \mathrm{M})+$ acetate $(200 \mu \mathrm{M})$ & $54.8 \pm 2.2 \mathrm{NS}$
\end{tabular}

Neurons were preincubated for $30 \mathrm{~min}$ with or without $200 \mu \mathrm{M}$ sodium acetate and further incubated for 30 min with $200 \mu \mathrm{M} \mathrm{H}_{2} \mathrm{O}_{2}$ in either the presence or absence of sodium acetate. Neuronal survival was estimated $24 \mathrm{hr}$ later. Results are expressed as the percentage of surviving neurons compared with control cultures. Data are the mean \pm SEM of three independent experiments performed in triplicate. NS, Not significantly different from the corresponding values obtained in the absence of acetate (ANOVA followed by Bonferroni's test).

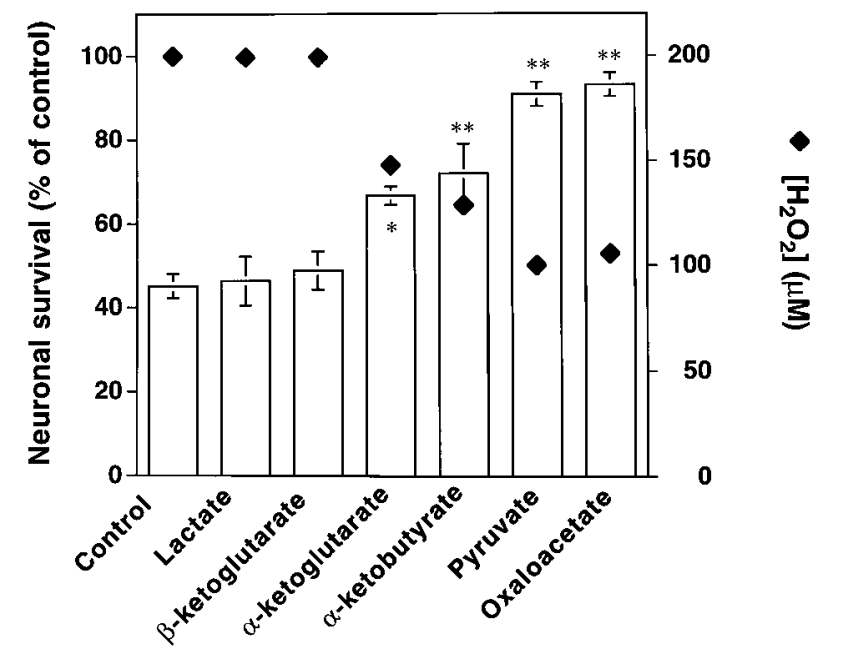

Figure 4. $\mathrm{H}_{2} \mathrm{O}_{2}$-scavenging capacities and neuroprotecting properties of various $\alpha$-ketoacids. A $200 \mu \mathrm{M}$ concentration of $\mathrm{H}_{2} \mathrm{O}_{2}$ was incubated with 2 mm sodium lactate, $\beta$-ketoglutarate, $\alpha$-ketoglutarate, $\alpha$-ketobutyrate, pyruvate, or oxaloacetate in Krebs' bicarbonate buffer for $2 \mathrm{~min}$ at $37^{\circ} \mathrm{C}$ in the absence of cells. The residual concentration of $\mathrm{H}_{2} \mathrm{O}_{2}$ ( filled symbols) was determined in each experimental condition. The error bars are not visible, because they are smaller than the symbols. In a separate set of experiments, cultured neurons were preincubated for $30 \mathrm{~min}$ with a $2 \mathrm{~mm}$ concentration of each compound and further incubated for 30 min with $200 \mu \mathrm{M} \mathrm{H} \mathrm{H}_{2} \mathrm{O}_{2}$ in their presence or absence. Neuronal survival was estimated $24 \mathrm{hr}$ later. Results are expressed as the percentage of living neurons compared with cultures not treated with $\mathrm{H}_{2} \mathrm{O}_{2}$. Data are the mean \pm SEM of three independent experiments each performed in triplicate. ${ }^{*} p<0.05 ;{ }^{*} p<0.01$; significantly different from the control value (ANOVA followed by Dunnett's test).

$\alpha$-ketobutyrate, which only possesses $\mathrm{H}_{2} \mathrm{O}_{2}$ scavenger properties, lactate, which is only an energy substrate metabolite (Schurr et al., 1988), or finally $\beta$-ketoglutarate, which is neither an $\mathrm{H}_{2} \mathrm{O}_{2}$ scavenger nor an energy substrate metabolite. These compounds were all added at a concentration of $2 \mathrm{~mm}$.

As shown in Figure 4, the ability of these different compounds to prevent $\mathrm{H}_{2} \mathrm{O}_{2}$ toxicity was related to their capacity to scavenge $\mathrm{H}_{2} \mathrm{O}_{2}$ and completely independent of their ability to be used as energy substrates. In particular, lactate was ineffective, whereas oxaloacetate strongly prevented $\mathrm{H}_{2} \mathrm{O}_{2}$ toxicity. In addition, the ability of the different $\alpha$-ketoacids (used at the same concentration, $2 \mathrm{~mm}$ ) to scavenge $\mathrm{H}_{2} \mathrm{O}_{2}$ was closely correlated with their capacity to protect neurons: oxaloacetate $=$ pyruvate $>\alpha$-ketoglutarate $=\alpha$-ketobutyrate (which is not an energy substrate metabolite). As lactate, $\beta$-ketoglutarate was ineffective (Fig. 4). 


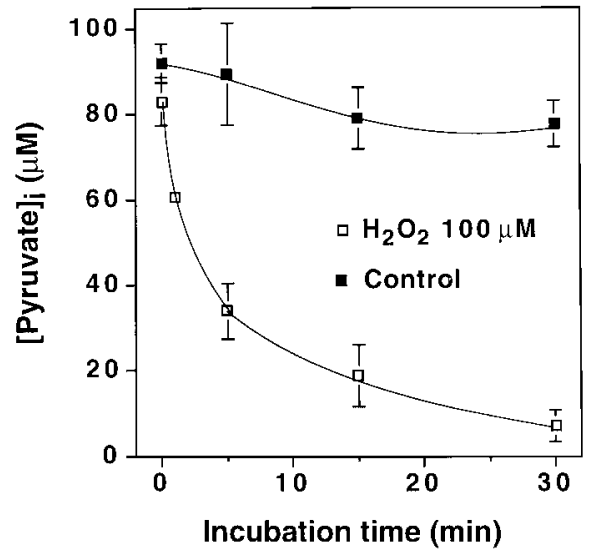

Figure 5. Exogenous $\mathrm{H}_{2} \mathrm{O}_{2}$ decreased intracellular pyruvate. Striatal neurons were incubated in Krebs' bicarbonate buffer with or without 100 $\mu \mathrm{M} \mathrm{H}_{2} \mathrm{O}_{2}$ for indicated times. Then, neuronal cultures were washed with $500 \mathrm{IU} / \mathrm{ml}$ catalase for $30 \mathrm{sec}$. Cells were subsequently treated as indicated in Materials and Methods. The cytosolic neuronal volume and the residual intracellular pyruvate were measured as described in Materials and Methods. Data are the mean \pm SEM of three independent experiments, each performed in triplicate.

\section{$\mathrm{H}_{2} \mathrm{O}_{2}$ decreased the cellular pyruvate content}

Conversely, because of its high membrane permeability (Halliwell, 1992), $\mathrm{H}_{2} \mathrm{O}_{2}$ may depress energy metabolism through the degradation of intracellular pyruvate (and other $\alpha$-ketoacids). Supporting this hypothesis, intracellular levels of pyruvate were markedly reduced when striatal neurons were exposed to $100 \mu \mathrm{M}$ $\mathrm{H}_{2} \mathrm{O}_{2}$ (Fig. 5). Indeed, pyruvate levels reached already one-third of basal levels within $5 \mathrm{~min}$ and became negligible after $30 \mathrm{~min}$, whereas intracellular levels of pyruvate were only slightly reduced under control conditions (Fig. 5).

\section{Influence of $\mathrm{pH}$ on the neuroprotective effect of pyruvate}

Three observations suggest that high concentrations of pyruvate can counteract its neuroprotective effects by inducing an intracellular acidification.

First, pyruvate, as lactate, is transported across the plasma membrane by the $\mathrm{H}^{+}$-monocarboxylate cotransporter (Poole and Halestrap, 1993). As shown in Figure 6, external pyruvate was rapidly transported into neurons, an equilibrium being reached between the external and internal concentrations in $5 \mathrm{~min}$. Accordingly, exposure of neurons to $10 \mathrm{~mm}$ pyruvate resulted in a sustained cytosolic acidification as measured with the use of the proton-sensitive dye carboxy SNARF-1 (Fig. 7).

Second, the rate of $\mathrm{H}_{2} \mathrm{O}_{2}$ degradation by pyruvate was reduced when the $\mathrm{pH}$ was decreased from 7.4 to 5.4 (Fig. 8).

Third, intracellular acidification potentiated $\mathrm{H}_{2} \mathrm{O}_{2}$-induced neuronal death (Fig. 8). Indeed, the neurotoxicity induced by 30 $\mu \mathrm{M} \mathrm{H}_{2} \mathrm{O}_{2}$ was strongly increased when extracellular $\mathrm{pH}(\mathrm{pHe})$ was decreased. It has been reported that $\mathrm{pHi}$ reaches approximately the pHe level by 10 min (Nedergaard et al., 1991). Intracellular acidification alone did not significantly alter the survival of striatal neurons except for pH 5.4 (Fig. 8).

Together, these results indicate that intracellular acidification induced by high concentrations of pyruvate not only moderates the scavenging capacity of pyruvate but also potentiates $\mathrm{H}_{2} \mathrm{O}_{2}$ neurotoxicity. The lack of protection of $10 \mathrm{~mm}$ pyruvate against menadione-induced toxicity might be the illustration of this paradox (Fig. 2).
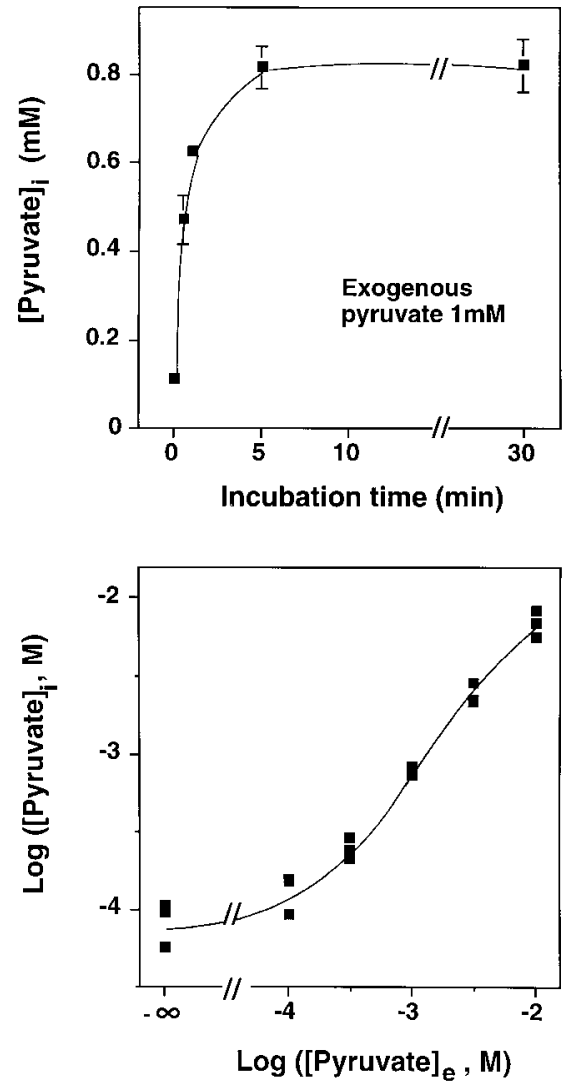

Figure 6. Pyruvate uptake by striatal neurons. Primary cultures of striatal neurons were incubated in Krebs' bicarbonate buffer at $37^{\circ} \mathrm{C}$ with 1 mM sodium pyruvate for the indicated times (top) or with increasing concentrations of pyruvate $\left(\left[\right.\right.$ Pyruvate $\left._{e}\right)$ for $10 \mathrm{~min}$ (bottom). Neurons were treated, and intracellular concentrations of pyruvate $\left(\left[\right.\right.$ Pyruvate $\left._{i}\right)$ were determined as described in Materials and Methods. Top, Data are the mean \pm SEM of two independent experiments, each performed in triplicate. Bottom, Individual results of three independent experiments, also performed in triplicate.

\section{DISCUSSION}

The present study demonstrates that extracellular pyruvate protects neurons against the neurotoxicity induced by exogenous or endogenously produced $\mathrm{H}_{2} \mathrm{O}_{2}$.

The antioxidant protective effect of $\alpha$-ketoacids has already been investigated both in vitro in several cell types (Andrae et al., 1985; O’Donnell-Tormey et al., 1987) and in vivo in whole organs such as heart or kidney (Cavallini et al., 1990; Salahudeen et al., 1991; Crestanello et al., 1995). However, to our knowledge, this process has never been investigated in neuronal cells. Our results indicate that pyruvate and related $\alpha$-ketoacids improve the survival of cultured neurons exposed to $\mathrm{H}_{2} \mathrm{O}_{2}$. Several observations suggest that the protective effect of pyruvate results rather from its ability to react with $\mathrm{H}_{2} \mathrm{O}_{2}$ to form acetate, water, and carbon dioxide than from the improvement of neuronal energy metabolism: (1) the neuroprotective effect of pyruvate was reproduced by several $\alpha$-ketoacids, which share with pyruvate the ability to react with $\mathrm{H}_{2} \mathrm{O}_{2}$; these compounds include $\alpha$-ketobutyrate, which is not an energy substrate; (2) lactate, which can be used instead of pyruvate as a neuronal energy substrate (Schurr et al., 1988), was ineffective in protecting neurons against $\mathrm{H}_{2} \mathrm{O}_{2}$-induced toxicity; and (3) the neuroprotective effect of the different $\alpha$-ketoacids against $\mathrm{H}_{2} \mathrm{O}_{2}$ toxicity was closely correlated with their ability to scavenge $\mathrm{H}_{2} \mathrm{O}_{2}$. 


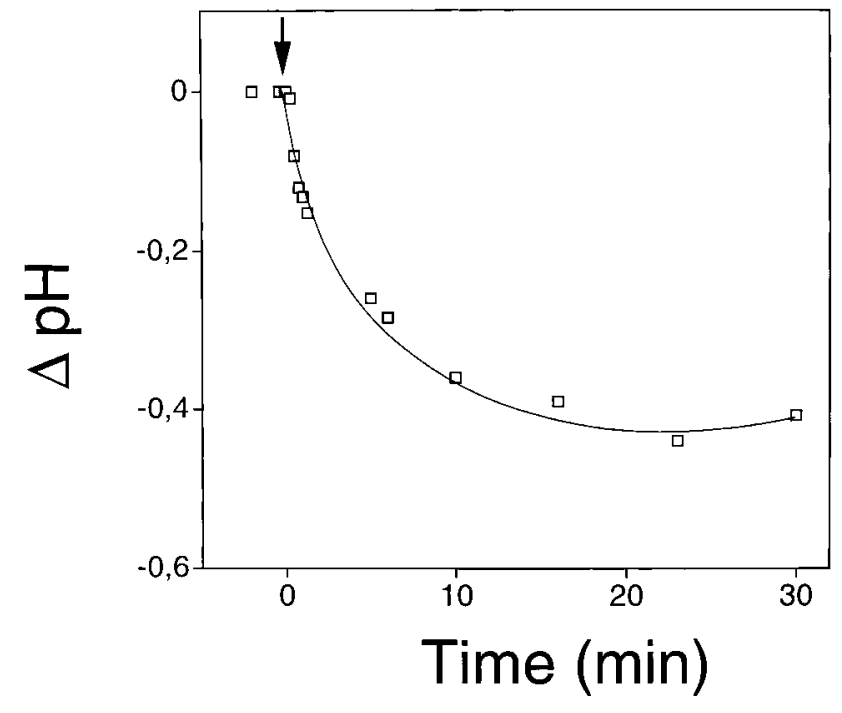

Figure 7. Cytosolic acidification by $10 \mathrm{~mm}$ sodium pyruvate. Cultured striatal neurons, previously loaded with carboxy-SNARF-1, were perfused for $30 \mathrm{~min}$ with $10 \mathrm{~mm}$ sodium pyruvate (arrow) in Krebs' bicarbonate buffer at a constant extracellular $\mathrm{pH}$ of 7.4. The exposure to pyruvate resulted in a long-lasting decrease of the 580:640 nm fluorescence ratio, determined as described in Materials and Methods. After pyruvate removal, the ratio increased, returning to its resting value by the end of a 25 min washout (data not shown). Each point is the mean from 14 cells. Two other independent experiments gave similar results.

As estimated by microdialysis in the ischemic striatum, the concentration of $\mathrm{H}_{2} \mathrm{O}_{2}$ can reach as much as $100 \mu \mathrm{M}$ during the reperfusion phase (Hyslop et al., 1995). In this situation, $\mathrm{H}_{2} \mathrm{O}_{2}$ is believed to be produced by cells located in the ischemic brain area and released into the extracellular space. Our results indicate that striatal neurons exposed to menadione also produce and release $\mathrm{H}_{2} \mathrm{O}_{2}$ in the incubating medium, and that pyruvate protects striatal neurons against the quinone-induced toxicity. Supporting this statement and showing that released $\mathrm{H}_{2} \mathrm{O}_{2}$ contributes to the toxic effect of menadione, the addition of catalase into the incubating medium partially protected the striatal neurons from the menadione-induced neurotoxicity. The higher neuroprotective effect of pyruvate can be related to its capacity to enter the cells and therefore to scavenge intracellular $\mathrm{H}_{2} \mathrm{O}_{2}$. Such beneficial effects of pyruvate have already been observed in human breast carcinoma cells and in the LLC-PK 1 cells derived from the renal tubular epithelium (Nath et al., 1995).

When striatal neurons are exposed to menadione, $\mathrm{H}_{2} \mathrm{O}_{2}$ is produced in the vicinity of free iron sources such as microsomes and mitochondria (Nath et al., 1995). Some toxic hydroxyl radicals could thus be formed before the scavenging action of pyruvate toward $\mathrm{H}_{2} \mathrm{O}_{2}$. This could explain why the protective effect of pyruvate against menadione-induced toxicity was less pronounced than that observed under the exposure of striatal neurons to exogenous $\mathrm{H}_{2} \mathrm{O}_{2}$.

Our study also indicates that at high concentration, pyruvate induces an intracellular acidification, which probably interferes with its neuroprotective effect. The cytosolic acidification of striatal neurons induced by $10 \mathrm{~mm}$ pyruvate may result from the $\mathrm{H}^{+}$ cotransport across the plasma membrane by the specific $\mathrm{H}^{+}$monocarboxylate cotransporter (Nedergaard and Goldman, 1993; Poole and Halestrap, 1993) and to a lesser extent from the diffusion of undissociated pyruvic acid (Bakker and Van Dam,
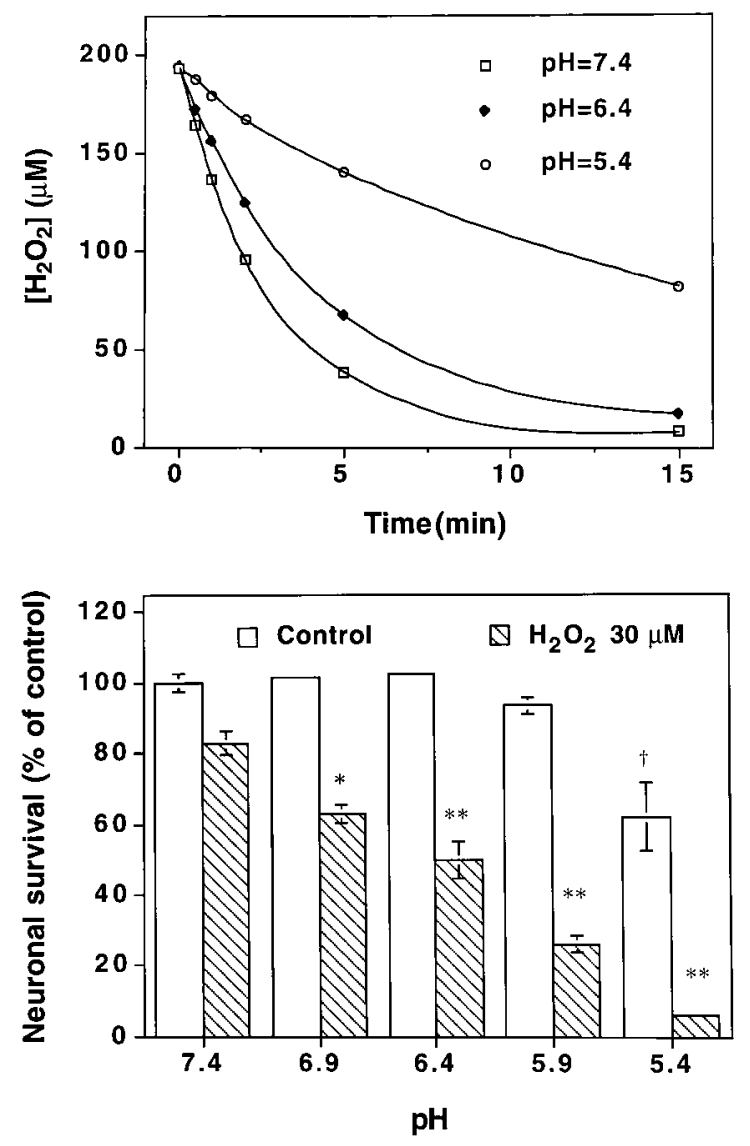

Figure 8. Influence of $\mathrm{pH}$ on the neuroprotective effect of pyruvate. Top, Kinetics of $\mathrm{H}_{2} \mathrm{O}_{2}$ degradation by pyruvate in acid solutions. Pyruvate (2 $\mathrm{mM})$ and $\mathrm{H}_{2} \mathrm{O}_{2}(200 \mu \mathrm{M})$ were incubated at $37^{\circ} \mathrm{C}$ in the absence of cells in HEPES-buffered salt solutions adjusted to different $\mathrm{pH}$ for increasing times. The residual concentrations of $\mathrm{H}_{2} \mathrm{O}_{2}$ were determined as described in Materials and Methods. Data are the mean \pm SEM of three independent experiments, each performed in triplicate. The error bars are not visible, because they are smaller than the symbols. Bottom, Neurotoxic effects of $\mathrm{H}_{2} \mathrm{O}_{2}$ in acid solutions. Cultured neurons were preincubated for $15 \mathrm{~min}$ and then incubated for $30 \mathrm{~min}$ with or without $30 \mu \mathrm{M} \mathrm{H} \mathrm{H}_{2} \mathrm{O}_{2}$ in HEPES-buffered salt solutions adjusted to different $\mathrm{pH}$. Neuronal survival was estimated $24 \mathrm{hr}$ later. Results are expressed as the percentage of living neurons compared with control cultures incubated at $\mathrm{pH} 7.4$ in the absence of $\mathrm{H}_{2} \mathrm{O}_{2}$. Data are the mean \pm SEM of three independent experiments, each performed in triplicate. ${ }^{\dagger} p<0.01$; significantly different from the control value; ${ }^{*} p<0.05$; ${ }^{*} p<<0.01$; significantly different from the value obtained in the presence of $\mathrm{H}_{2} \mathrm{O}_{2}$ at $\mathrm{pH} 7.4$ (ANOVA followed by Dunnett's test).

1974). Furthermore, intracellular acidification enhanced the neurotoxic effect of $\mathrm{H}_{2} \mathrm{O}_{2}$ and reduced the rate of $\mathrm{H}_{2} \mathrm{O}_{2}$ scavenging by pyruvate, as already reported by Melzer and Schmidt (1988). The reduction of intracellular $\mathrm{pH}$ is known to induce the release of active iron from ferritin (Funk et al., 1985; Braughler and Hall, 1989), a process that leads to an enhanced production of $\mathrm{OH}^{*}$ (Siesjö et al., 1985; Rehncrona et al., 1989). In addition, small reductions in pHi can inhibit metabolic enzymes (Busa, 1986). All of these events could contribute to an enhanced neurotoxic effect of $\mathrm{H}_{2} \mathrm{O}_{2}$ intervening under the intracellular acidification induced by $10 \mathrm{~mm}$ pyruvate. The optimal neuroprotective concentration of pyruvate should be reached when its $\mathrm{H}_{2} \mathrm{O}_{2}$-scavenging capacity exceeds its adverse effect linked to the cytosolic acidification. When striatal neurons were exposed to menadione, this optimal neuroprotective concentration of pyruvate was $\sim 1 \mathrm{~mm}$. 
According to O'Donnell-Tormey et al. (1987), pyruvate is the sole $\alpha$-ketoacid that is secreted, its extracellular concentration reaching almost its intracellular concentration. Therefore, in pathological situations such as brain ischemia or trauma, endogenously produced pyruvate could be considered an extracellular antioxidant. Indeed, under these circumstances, released $\mathrm{H}_{2} \mathrm{O}_{2}$, which exerts its toxic effect through a paracrine process, could be scavenged by external pyruvate. We have recently demonstrated that astrocytes strongly protect neurons against external $\mathrm{H}_{2} \mathrm{O}_{2}$ by degrading the oxidant and that catalase is the main astrocytic enzyme activity responsible for this neuroprotective effect. If $\mathrm{H}_{2} \mathrm{O}_{2}$ scavenging by external pyruvate occurs in vivo, the beneficial role of astrocytes should depend not only on their hydrogen peroxidase activity but also on their glycolytic activity and their capacity to release pyruvate. Pellerin and Magistretti (1994) have demonstrated that glutamate, which is largely released under ischemia, can stimulate glycolysis in astrocytes and can increase lactate and pyruvate release from these cells. Therefore, pyruvate, which originates from astrocytes and which has a release process that is submitted to regulation, might contribute to neuronal protection.

Glucose metabolism impairment has been reported to occur in neurodegenerative disorders such as Alzheimer's and Huntington's diseases or amyotrophic lateral sclerosis (Beal, 1992). Therefore, the decline in pyruvate levels that may occur in such pathological situations should result not only in a deficit of energy metabolism but also in a reduced antioxidant effect of this agent. This reduced antioxidant state is likely to contribute to a higher neuronal vulnerability to reactive oxygen species and consequently to neuronal death.

Unlike exogenous catalase, pyruvate and other $\alpha$-ketoacids can cross the blood-brain barrier (Oldendorf, 1973; Conn et al., 1983). Therefore, our study suggests that pyruvate and other $\alpha$-ketoacids could be of therapeutic value in pathological situations, such as ischemia-reperfusion or trauma, in which acute production of $\mathrm{H}_{2} \mathrm{O}_{2}$ is believed to play a critical role. Indeed, intravenous infusions of pyruvate leading to millimolar plasma concentrations of this $\alpha$-ketoacid are tolerated without apparent adverse effect in humans (Dijkstra et al., 1984).

\section{REFERENCES}

Andrae U, Singh J, Ziegler-Skylakakis K (1985) Pyruvate and related $\alpha$-ketoacids protect mammalian cells in culture against hydrogen peroxide-induced cytotoxicity. Toxicol Lett 28:93-98.

Bakker EP, Van Dam K (1974) The movement of monocarboxylic acids across phospholipid membranes: evidence for an exchange diffusion between pyruvate and other monocarboxylate ions. Biochim Biophys Acta 339:285-289.

Beal MF (1992) Does impairment of energy metabolism result in excitotoxic neuronal death in neurodegenerative illnesses? Ann Neurol 31:119-130.

Berridge MV, Tan AS (1993) Characterization of the cellular reduction of 3-(4,5-dimethylthiazol-2-yl)-2,5-diphenyltetrazolium bromide (MTT): subcellular localization, substrate dependence, and involvement of mitochondrial electron transport in MTT reduction. Arch Biochem Biophys 303:474-482.

Bradford MM (1976) A rapid and sensitive method for the quantitation of microgram quantities of protein utilizing the principle of protein dye binding. Anal Biochem 72:248-254.

Braughler JM, Hall ED (1989) Central nervous system trauma and stroke. I. Biochemical considerations for oxygen radical formation and lipid peroxidation. Free Radic Biol Med 6:289-301.

Bunton CA (1949) Oxidation of $\alpha$-diketones and $\alpha$-keto-acids by hydrogen peroxide. Nature 163:444-446.
Busa WB (1986) Mechanisms and consequences of pH-mediated cell regulation. Annu Rev Physiol 48:389-402.

Cavallini L, Valente M, Rigobello MP (1990) The protective action of pyruvate on recovery of ischemic rat heart: comparison with other oxidizable substrates. J Mol Cell Cardiol 22:143-154.

Conn AR, Fell DI, Steele RD (1983) Characterization of $\alpha$-keto acid transport across blood-brain barrier in rats. Am J Physiol 245:E253-E260.

Crestanello JA, Kamelgard J, Whitman GJR (1995) The cumulative nature of pyruvate's dual mechanism for myocardial protection. J Surg Res 59:198-204.

Desagher S, Glowinski J, Prémont J (1996) Astrocytes protect neurons from hydrogen peroxide toxicity. J Neurosci 16:2553-2562.

Dijkstra U, Gabreëls F, Joosten E, Wevers R, Lamers K, Doesburg W, Renier W (1984) Friedreich's ataxia: intravenous pyruvate load to demonstrate a defect in pyruvate metabolism. Neurology 34:1493-1497.

Doroshow JH (1986) Role of hydrogen peroxide and hydroxyl radical formation in the killing of Ehrlich tumor cells by anticancer quinones. Proc Natl Acad Sci USA 83:4514-4518.

El Etr M, Cordier J, Glowinski J, Premont J (1989) A neuro-glial cooperativity is required for the potentiation by 2-chloroadenosine of the muscarinic-sensitive phospholipase $\mathrm{C}$ in the striatum. J Neurosci 9:1473-1480.

Fenton HJH (1894) Oxidation of tartaric acid in the presence of iron. J Chem Soc 65:899-910.

Funk F, Lenders J-P, Crichton RR, Schneider W (1985) Reductive mobilisation of ferritin iron. Eur J Biochem 152:167-172.

Garcia CK, Goldstein JL, Pathak RK, Anderson RGW, Brown MS (1994) Molecular characterization of a membrane transporter for lactate, pyruvate, and other monocarboxylates: implications for the Cori cycle. Cell 76:865-873.

Halliwell B (1992) Reactive oxygen species and the central nervous system. J Neurochem 59:1609-1623.

Holleman MAF (1904) Notice sur l'action de l'eau oxygénée sur les acides $\alpha$-cétoniques et sur les dicétones 1.2. Recl Trav Chim Pays Bas Belg 23:169-171.

Hyslop PA, Zhang Z, Pearson DV, Phebus LA (1995) Measurement of striatal $\mathrm{H}_{2} \mathrm{O}_{2}$ by microdialysis following global forebrain ischemia and reperfusion in the rat: correlation with the cytotoxic potential of $\mathrm{H}_{2} \mathrm{O}_{2}$ in vitro. Brain Res 671:181-186.

Lowry OH, Passonneau JV (1972) A flexible system of enzymatic analysis. New York: Academic.

Melzer E, Schmidt H (1988) Carbon isotope effects on the decarboxylation of carboxylic acids. Biochem J 252:913-915.

Nath KA, Ngo EO, Hebbel RP, Croatt AJ, Zhou B, Nutter LM (1995) $\alpha$-ketoacids scavenge $\mathrm{H}_{2} \mathrm{O}_{2}$ in vitro and in vivo and reduce menadioneinduced DNA injury and cytotoxicity. Am J Physiol 268:C227-C236.

Nedergaard M, Goldman SA (1993) Carrier-mediated transport of lactic acid in cultured neurons and astrocytes. Am J Physiol 265:R282-R289.

Nedergaard M, Goldman SA, Desai S, Pulsinelli WA (1991) Acidinduced death in neurons and glia. J Neurosci 11:2489-2497.

O'Donnell-Tormey J, Nathan CF, Lanks K, DeBoer CJ, De la Harpe J (1987) Secretion of pyruvate. An antioxidant defense of mammalian cells. J Exp Med 165:500-514.

Olanow CW (1993) A radical hypothesis for neurodegeneration. Trends Neurosci 16:439-444.

Oldendorf WH (1973) Carrier-mediated blood-brain barrier transport of short chain monocarboxylic organic acids. Am J Physiol 224:1450-1453.

Pellerin L, Magistretti PJ (1994) Glutamate uptake into astrocytes stimulates aerobic glycolysis: a mechanism coupling neuronal activity to glucose utilization. Proc Natl Acad Sci USA 91:10625-10629.

Poole RC, Halestrap AP (1993) Transport of lactate and other monocarboxylates across mammalian plasma membranes. Am J Physiol 264:C761-C782.

Rehncrona S, Hauge HN, Siesjö BK (1989) Enhancement of ironcatalyzed free radical formation by acidosis in brain homogenates: difference in effect by lactic acid and $\mathrm{CO}_{2}$. J Cereb Blood Flow Metab 9:65-70.

Rottenberg H (1979) The measurement of membrane potential and $\Delta \mathrm{pH}$ in cells, organelles, and vesicles. In: Methods in enzymology (Fleisher S, Packer L, eds), pp 547-569. New York: Academic.

Salahudeen AK, Clark EC, Nath KA (1991) Hydrogen peroxideinduced renal injury. A protective role for pyruvate in vitro and in vivo. J Clin Invest 88:1886-1893. 
Schurr A, West CA, Rigor BM (1988) Lactate-supported synaptic function in the rat hippocampal slice preparation. Science 240:1326-1328.

Siesjö BK, Bendenk G, Koide T, Westerberg E, Wieloch T (1985) Influence of acidosis on lipid peroxidation in brain tissues in vitro. J Cereb Blood Flow Metab 5:253-258.

Siesjö BK, Agardh CD, Bengtsson F (1989) Free radicals and brain damage. Cerebrovasc Brain Metab Rev 1:165-211.

Simonian NA, Coyle JT (1996) Oxidative stress in neurodegenerative diseases. Annu Rev Pharmacol Toxicol 36:83-106.

Slater TF, Sawyer B, Sträubli U (1963) Studies on succinate-tetrazolium reductase systems. III. Points of coupling of four different tetrazolium salts. Biochim Biophys Acta 77:383-393.
Thomas JA, Buchsbaum RN, Zimniak A, Racker E (1979) Intracellular $\mathrm{pH}$ measurements in Ehrlich ascites tumor cells utilizing spectroscopic probes generated in situ. Biochemistry 18:2210-2218.

Thor H, Smith MT, Hartzell P, Bellomo G, Jewell SA, Orrenius S (1982) The metabolism of menadione (2-methyl-1,4-naphtoquinone) by isolated hepatocytes. J Biol Chem 257:12419-12425.

Traystman RJ, Kirsch JR, Koehler RC (1991) Oxygen radical mechanisms of brain injury following ischemia and reperfusion. J Appl Physiol 71:1185-1195.

Whitaker JE, Haugland RP, Prendergast FG (1991) Spectral and photophysical studies of benzo[c]xanthene dyes: dual emission $\mathrm{pH}$ sensors. Anal Biochem 194:330-344. 